\title{
Effect of CuO Nanoparticles over Isolated Bacterial Strains from Agricultural Soil
}

\author{
Sandra I. Concha-Guerrero, ${ }^{1}$ Elcia Margareth Souza Brito, ${ }^{2}$ \\ Hilda A. Piñón-Castillo, ${ }^{1}$ S. H. Tarango-Rivero, ${ }^{3}$ César A. Caretta, ${ }^{4}$ \\ Antonia Luna-Velasco, ${ }^{1}$ Robert Duran, ${ }^{5}$ and Erasmo Orrantia-Borunda ${ }^{1}$ \\ ${ }^{1}$ Center for Research in Advanced Materials, Chihuahua, CHIH, Mexico \\ ${ }^{2}$ Ingeniería Ambiental, Departamento de Ingeniería Civil, DI-CGT, Universidad de Guanajuato, Guanajuato, GTO, Mexico \\ ${ }^{3}$ Campo Experimental Delicias, INIFAP, CHIH, Mexico \\ ${ }^{4}$ Departamento de Astronomía, DCNyE-CGT, Universidad de Guanajuato, Guanajuato, GTO, Mexico \\ ${ }^{5}$ Equipe Environment et Microbiologie, UMR IPREM5254, IBEAS, Université de Pau et des Pays de l'Adour, Pau, France
}

Correspondence should be addressed to Sandra I. Concha-Guerrero; sandra.concha@cimav.edu.mx

and Elcia Margareth Souza Brito; emsbrito@gmail.com

Received 26 June 2014; Accepted 4 December 2014; Published 31 December 2014

Academic Editor: Mallikarjuna N. Nadagouda

Copyright (C) 2014 Sandra I. Concha-Guerrero et al. This is an open access article distributed under the Creative Commons Attribution License, which permits unrestricted use, distribution, and reproduction in any medium, provided the original work is properly cited.

\begin{abstract}
The increased use of the nanoparticles (NPs) on several processes is notorious. In contrast the ecotoxicological effects of NPs have been scarcely studied. The main current researches are related to the oxide metallic NPs. In the present work, fifty-six bacterial strains were isolated from soil, comprising 17 different OTUs distributed into 3 classes: Bacilli (36 strains), Flavobacteria (2 strains), and Gammaproteobacteria (18 strains). Copper oxide nanoparticles (CuONPs) were synthesized using a process of chemical precipitation. The obtained CuONPs have a spherical shape and primary size less than $17 \mathrm{~nm}$. Twenty-one strains were used to evaluate the cytotoxicity of CuONPs and 11 of these strains showed high sensibility. Among those 11 strains, 4 (Brevibacillus laterosporus strain CSS8, Chryseobacterium indoltheticum strain CSA28, and Pantoea ananatis strains CSA34 and CSA35) were selected to determine the kind of damage produced. The CuONPs toxic effect was observed at expositions over $25 \mathrm{mg} \cdot \mathrm{L}^{-1}$ and the damage to cell membrane above $160 \mathrm{mg} \cdot \mathrm{L}^{-1}$. The electron microscopy showed the formation of cavities, holes, membrane degradation, blebs, cellular collapse, and lysis. These toxic effects may probably be due to the ions interaction, the oxide-reduction reactions, and the generation of reactive species.
\end{abstract}

\section{Introduction}

The use of nanoparticles (NPs) has largely increased in the last years, the expected projection for the engineered nanomaterials production reaching more than 58,000 tons for 2012-2020 [1]. The waste generated by the NPs industry has been demonstrated to affect directly the environment, mainly soil ecosystems, followed by water and air ones [2-6]. Besides, it was found that NPs contamination might result in additive, synergistic, or antagonistic toxicity $[7,8]$ affecting the entire food chain.
Although the environmental effect of some nanomaterials such as carbon nanotubes, metal, oxides, and zero-valent metal NPs has been well studied [9], information about its interaction and damage on native bacterial communities is still scarce. Soil microbial communities are involved in several biogeochemical cycles such as carbon, nitrogen, sulfur, and phosphorus ones $[9,10]$. Thus, even a little perturbation in the structure and composition of microbial communities may induce modifications in the surrounding environment and vice versa. It is known that the bactericidal efficiency of NPs depends on the microorganism type, for instance, copper 


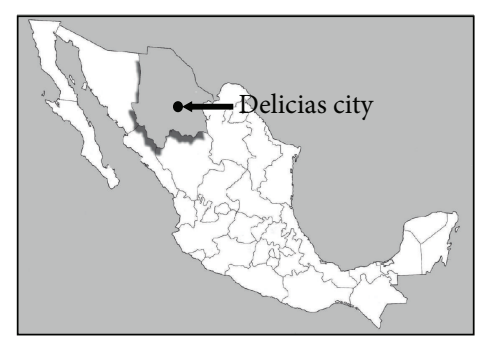

(a)

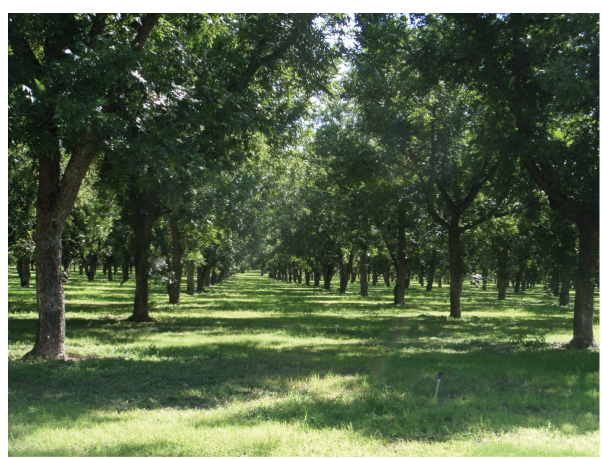

(c)

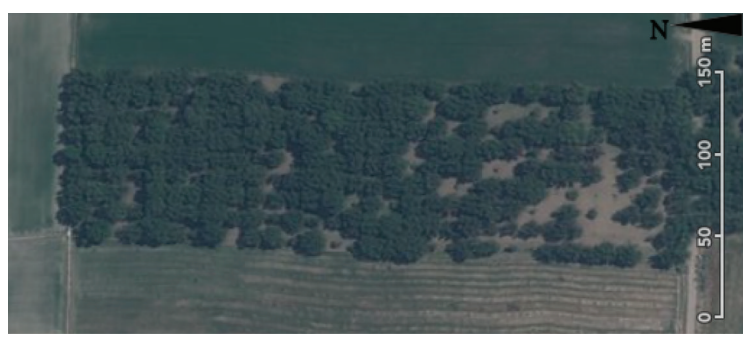

(b)

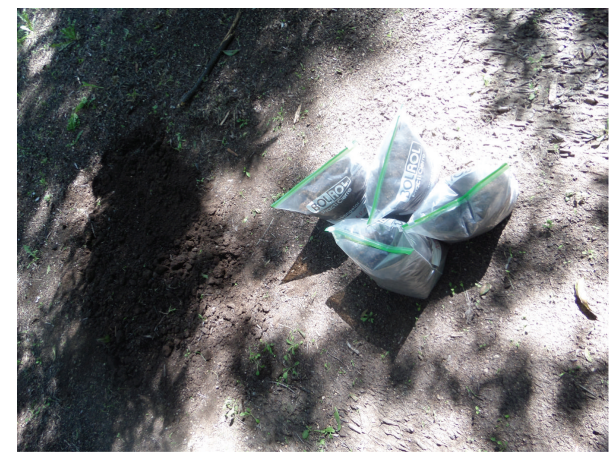

(d)

Figure 1: Location of Delicias city, Chihuahua, México (a); aerial (b) and ground (c) views of the pecan orchard; and a view of the sampled soil (d).

nanoparticles (CuNPs) showed more inhibitory activity on bacterial than on fungal strains [11]. Furthermore, there are reports that the increased copper $(\mathrm{Cu})$ concentrations affect the soil microorganisms modifying their number, biomass, activity, and diversity [12-15], while the bactericidal effect of copper oxide nanoparticles (CuONPs) has just been reported for type strains [11, 16-20]. Moreover, Kim et al. (2007) [21] found that the biocide efficiency of silver nanoparticles (AgNPs) over microorganisms depends on cell wall composition, while Niazi and $\mathrm{Gu}$ [22] show that cell damage, such as membrane disorganization, generation of reactive oxygen species (ROS), and DNA damages, can be influenced by the surface area and composition of NPs. Nevertheless despite the importance of soil bacterial communities on homeostasis of geochemical cycles, and the intensive use of the NPs, only few studies have been performed to elucidate the impact of NPs on soil bacterial communities [6, 22-25]. The protection of soil microbial biomass and diversity is one of the major challenges for the future years, especially because they play an important role on soil usage and maintenance. The sustainable use of these resources may not be guaranteed if the nutrient cycles change their proper functioning [26, 27]. It is thus urgent to obtain information on how NPs could affect bacterial communities in order to mitigate their environmental impact.

The aim of this work was to determine the mechanisms involved in the CuONP interaction with native bacterial strains. First, we isolated wild bacterial strains from agricultural soil, which were characterized by $16 \mathrm{~S}$ rRNA gene sequencing. Then, CuONPs/bacterial cells interactions were examined using four of these bacterial strains, which were selected by their importance in the soil biogeochemical cycles and also by their sensibility to CuONPs on exposition tests.

\section{Materials and Methods}

2.1. Sampling Site. In this work soil samples were collected from a pecan agricultural soil at Delicias city, Chihuahua state, México (Figure 1), in July 2012. The superficial litterfall was removed and 12 subsamples (maximum $10 \mathrm{~cm}$ depth) were obtained being $20 \mathrm{~m}$ far from each other. Afterwards they were mixed into a single composite sample, sieved $(>2 \mathrm{~mm})$, and immediately conserved at $4^{\circ} \mathrm{C}$ until use.

2.2. Physicochemical Characterization of Soil Sample. The soil characterization was performed in the Department of Agrotechnological Sciences of the Chihuahua University (FACIATEC). The soil texture presented sand $71 \%$, silt $13 \%$, and clay $16 \%$. Other characteristics are summarized in Table 1 . The crystallinity of the soil was further characterized by X-ray diffractometer (XRD, MDP Phillips $\mathrm{X}^{\prime}$ pert PRO). The data was analyzed with HighScore software. The samples for morphology and soil structure analyses were prepared according to Maldonado et al. [28], which were done using a Jeol JSM 7401F field emission scanning electron microscope (SEM) while the elemental analysis was performed by energy dispersive X-ray (EDX, Oxford Inca PentaFETX3) coupled to SEM (see more details below).

2.3. Microbiological Characterization. The microbial characterization was first performed with culture dependent techniques to determine the bacterial abundance, by using colony forming unit (CFU) counts and most probable number 
TABLE 1: Pedologic and microbial soil characteristics.

\begin{tabular}{|c|c|}
\hline Parameters & \\
\hline \multicolumn{2}{|l|}{ Physical properties } \\
\hline$\%$ sand & 71 \\
\hline$\%$ silt & 13 \\
\hline$\%$ clay & 16 \\
\hline $\mathrm{pH}$ & 6.80 \\
\hline$\%$ organic matter & 0.29 \\
\hline$\% \mathrm{CaCO}_{3}$ & 1.54 \\
\hline C.H. $\left(\mathrm{cm} \cdot \mathrm{h}^{-1}\right)$ & 5.71 \\
\hline$\%$ saturation & 42.5 \\
\hline C.E. $\left(\mathrm{mmhos} \cdot \mathrm{cm}^{-1}\right)$ & 0.75 \\
\hline \multicolumn{2}{|l|}{ Fertility } \\
\hline $\mathrm{N}-\mathrm{NO}_{3}\left(\mathrm{~kg} \cdot \mathrm{ha}^{-1}\right)$ & $2.16 \times 10^{3}$ \\
\hline $\mathrm{P}\left(\mathrm{kg} \cdot \mathrm{ha}^{-1}\right)$ & 31.0 \\
\hline $\mathrm{K}\left(\mathrm{mg} \cdot \mathrm{L}^{-1}\right)$ & $3.62 \times 10^{2}$ \\
\hline $\mathrm{Ca}\left(\mathrm{mg} \cdot \mathrm{L}^{-1}\right)$ & $10.17 \times 10^{3}$ \\
\hline $\operatorname{Mg}\left(\mathrm{mg} \cdot \mathrm{L}^{-1}\right)$ & $9.62 \times 10^{2}$ \\
\hline $\mathrm{Na}\left(\mathrm{mg} \cdot \mathrm{L}^{-1}\right)$ & $20.62 \times 10^{2}$ \\
\hline $\mathrm{Cu}\left(\mathrm{mg} \cdot \mathrm{L}^{-1}\right)$ & 0.60 \\
\hline $\mathrm{Fe}\left(\mathrm{mg} \cdot \mathrm{L}^{-1}\right)$ & 1.80 \\
\hline $\operatorname{Mn}\left(\mathrm{mg} \cdot \mathrm{L}^{-1}\right)$ & 5.22 \\
\hline $\mathrm{Zn}\left(\mathrm{mg} \cdot \mathrm{L}^{-1}\right)$ & 71.82 \\
\hline \multicolumn{2}{|l|}{ Microbiological properties } \\
\hline \multicolumn{2}{|l|}{ CFU } \\
\hline AGEL (Actinobacteria) $\left(\mathrm{CFU} \cdot \mathrm{mL}^{-1}\right)$ & $5.3 \times 10^{2}$ \\
\hline M9 (coliform) $\left(\mathrm{CFU} \cdot \mathrm{mL}^{-1}\right)$ & $8.6 \times 10^{4}$ \\
\hline YPS (aerobic bacteria, Bacilli) $\left(\mathrm{CFU} \cdot \mathrm{mL}^{-1}\right)$ & $5.2 \times 10^{4}$ \\
\hline LB (enteric bacteria) $\left(\mathrm{CFU} \cdot \mathrm{mL}^{-1}\right)$ & $5.9 \times 10^{4}$ \\
\hline MPN (cell· [gsoil] $\left.]^{-1}\right)$ & $2.1 \times 10^{5}$ \\
\hline $\mathrm{FDA}\left([\mu \mathrm{gFDA}] \cdot \mathrm{mL}^{-1}\right)$ & $21.6 \pm 0.021$ \\
\hline
\end{tabular}

(MPN) as well as the total microbial activity and metabolic activities.

The CFU counts were performed in different culture media in order to obtain the largest possible number of isolates. The culture media used are listed in the following: (1) the modified M9 minimal medium (47 mM Na $2 \mathrm{HPO}_{4}$, $22 \mathrm{mM} \mathrm{KH}_{2} \mathrm{PO}_{4}, 8.6 \mathrm{mM} \mathrm{NaCl}, 2.2 \%$ dextrose, $15 \mathrm{~g} \cdot \mathrm{L}^{-1}$ bacteriological agar, $1.6 \% \mathrm{MgSO}_{4}, 0.2 \%$ vitamins, and $0.2 \%$ trace elements) [29]; (2) the modified AGEL medium $\left(2 \mathrm{~g} \cdot \mathrm{L}^{-1}\right.$ yeast extract, $1 \mathrm{~g} \cdot \mathrm{L}^{-1} \mathrm{KH}_{2} \mathrm{PO}_{4}, 5 \mathrm{~mL}$ glycerol, $15 \mathrm{~g} \cdot \mathrm{L}^{-1}$ bacteriological agar, and $5 \mathrm{~mL}$ Crystal-violet 1\%), specific for Actinobacteria; (3) the nutritionally rich LB medium (Luria-Bertani: $10 \mathrm{~g} \cdot \mathrm{L}^{-1}$ peptone from casein, $5 \mathrm{~g} \cdot \mathrm{L}^{-1}$ yeast extract, $10 \mathrm{~g} \cdot \mathrm{L}^{-1}$ $\mathrm{NaCl}$, and $15 \mathrm{~g} \cdot \mathrm{L}^{-1}$ bacteriological agar), for the growth of enteric bacteria; (4) the YPS medium $\left(3 \mathrm{gL}^{-1}\right.$ protease peptone, $3 \mathrm{gL}^{-1}$ yeast extract, $2 \mathrm{mM} \mathrm{CaCl}_{2}$, and $2 \mathrm{mM} \mathrm{MgSO}_{4}$ ) [30], used to isolate total aerobic bacteria and Bacilli; (5) the MMB medium $\left(3.7 \mathrm{gL}^{-1} \mathrm{Na}_{2} \mathrm{HPO}_{4}, 0.98 \mathrm{gL}^{-1} \mathrm{KH}_{2} \mathrm{PO}_{4}\right.$, $0.5 \mathrm{gL}^{-1} \mathrm{NH}_{4} \mathrm{Cl}, 0.03 \mathrm{gL}^{-1} \mathrm{MgSO}_{4}, 0.5 \mathrm{gL}^{-1}$ dextrose, $0.4 \mathrm{gL}^{-1}$ protease peptone, $0.01 \mathrm{M}$ Tris- $\mathrm{HCl}, 1 \mathrm{~mL}$ vitamins, and $0.02 \%$ trace elements) [31], employed for isolating the heterotrophic bacteria; (6) the soy medium $\left(15 \mathrm{~g} \cdot \mathrm{L}^{-1}\right.$ peptone from casein,
$5 \mathrm{~g} \cdot \mathrm{L}^{-1}$ peptone from soy, $3 \mathrm{~g} \cdot \mathrm{L}^{-1}$ yeast extract, $5 \mathrm{~g} \cdot \mathrm{L}^{-1} \mathrm{dex}-$ trose, $5 \mathrm{~g} \cdot \mathrm{L}^{-1} \mathrm{NaCl}$, and $15 \mathrm{~g} \cdot \mathrm{L}^{-1}$ bacteriological agar) as a nutritional rich medium for isolating aerobic and anaerobic microorganisms; and (7) the R2A medium $\left(0.5 \mathrm{~g} \cdot \mathrm{L}^{-1}\right.$ yeast extract, $0.5 \mathrm{~g} \cdot \mathrm{L}^{-1}$ protease peptone, $0.5 \mathrm{~g} \cdot \mathrm{L}^{-1}$ tryptone, $0.5 \mathrm{~g} \cdot \mathrm{L}^{-1}$ dextrose, $0.5 \mathrm{~g} \cdot \mathrm{L}^{-1}$ starch, $0.3 \mathrm{~g} \cdot \mathrm{L}^{-1}$ sodium pyruvate, $0.3 \mathrm{~g} \cdot \mathrm{L}^{-1} \mathrm{~K}_{2} \mathrm{HPO}_{4}$, and $15 \mathrm{~g} \cdot \mathrm{L}^{-1}$ bacteriological agar) [32], a medium with a low nutrient content, appropriate for the development of slow growing or stressed bacteria. All morphologically distinct colonies observed in the solid plates were selected and submitted to an isolation process using a streak plate traditional method.

For MPN the MMB media, $3.7 \mathrm{gL}^{-1} \mathrm{Na}_{2} \mathrm{HPO}_{4}, 0.98 \mathrm{gL}^{-1}$ $\mathrm{KH}_{2} \mathrm{PO}_{4}, 0.5 \mathrm{gL}^{-1} \mathrm{NH}_{4} \mathrm{Cl}, 0.03 \mathrm{gL}^{-1} \mathrm{MgSO}_{4}, 0.5 \mathrm{gL}^{-1} \mathrm{dex}-$ trose, $0.4 \mathrm{gL}^{-1}$ protease peptone, $0.01 \mathrm{M}$ Tris- $\mathrm{HCl}, 1 \mathrm{~mL}$ vitamins, and $0.02 \%$ trace elements [31], were used.

The total microbial activity was determined through fluorescein diacetate (FDA) hydrolysis [33]. The metabolic activity of soil community was assessed by Biolog Ecoplates (Biolog, Inc., Hayward, CA, USA) [34], which will be described below.

2.4. DNA Extraction and Phylogenetic Analysis of Isolates. Total genomic DNA extraction from each of the 56 isolated bacteria was performed using the Wizard Genomic DNA Purification Kit (Promega Corporation). Bacterial 16S rRNA gene was PCR-amplified using the 8F (AGAGTTTGATCCTGGCTAG) [35] and 1489R (TACCTTGTTACGACTTCA) [36] primers. The reaction was cycled with an initial denaturation step $\left(95^{\circ} \mathrm{C}\right.$ for $\left.5 \mathrm{~min}\right)$ followed by 35 cycles of denaturation step $\left(95^{\circ} \mathrm{C}\right.$ for $\left.45 \mathrm{~s}\right)$, annealing $\left(52^{\circ} \mathrm{C}\right.$ for $\left.45 \mathrm{~s}\right)$, elongation $\left(72^{\circ} \mathrm{C}\right.$ for $\left.1 \mathrm{~min}\right)$, and then a final elongation step $\left(72^{\circ} \mathrm{C}\right.$ for $\left.10 \mathrm{~min}\right)$. The PCR products were purified with Illustra GFX PCR DNA and Gel Band Purification Kit (GE Healthcare). The sequencing was carried out by Research and Advanced Studies Center of the National Polytechnic Institute (CINVESTAV-Irapuato, México). Sequence data were analyzed with BioEdit program and compared with the online database NCBI (http: //blast.ncbi.nlm.nih.gov/Blast.cgi). MAFFT software (multiple sequence alignment based on fast Fourier transform) was used for the alignment of sequences. The phylogenetic tree was constructed with Molecular Evolutionary Genetics Analysis v5.2 program [37] using the Jukes-Cantor model and the neighbour-joining algorithm. The significance of branching order was determined using bootstrap analysis with 1000 resampling data sets.

2.5. Synthesis and Characterization of CuONPs. The synthesis of CuONPs was prepared according to Lanje et al. [38]. The size and morphology of nanoparticles were analyzed using SEM (Jeol JSM 7401F) and field emission transmission electron microscopy (TEM). A suspension of the nanoparticles in ethanol $(1 \mathrm{~mL})$ was sonicated for $15 \mathrm{~min} .300 \mu \mathrm{L}$ of this solution was placed onto an aluminum support and then analyzed for SEM operated at $5.0 \mathrm{kV}$. TEM samples were prepared by putting one drop of the suspension onto nickel grids and the organic residues were cleaned using 
plasma (5 min) and finally were observed. The nanoparticles crystallinity was characterized by XRD. The data was again analyzed with HighScore software. The absorption spectrum of the colloidal solution was determined on Perkin Elmer UVvisible spectrophotometer.

2.6. Antibacterial Activity. The bactericidal effect of CuONP was analyzed against 21 representative bacterial isolates. The nanoparticles were dispersed in presterilized tridistilled water by sonication. Cells were grown and adjusted to $\mathrm{OD}_{620 \mathrm{~nm}}=0.1$. Fresh axenic cultures were inoculated in 96-well plates (final volume $200 \mu \mathrm{L}$ ), containing liquid culture medium, supplemented with various concentrations of CuONP $\left(0-100 \mathrm{mgL}^{-1}\right)$. After incubation $\left(12-18 \mathrm{~h}\right.$ at $\left.37^{\circ} \mathrm{C}\right)$ the bacterial growth was put in evidence according to the color developed using resazurin as indicator. The shift from blue to pink indicates the bacterial growth [39].

2.7. Carbon Source Utilization by the Four Bacterial Isolates. Bacterial carbon utilization fingerprints were generated using Biolog EcoPlates. These 96-well microplates contain three replicate wells of 31 carbon substrates: 6 amino acids, 10 carbohydrates, 7 carboxylic acids, 2 amines, 2 phenolic compounds, and 4 polymers. Each well also contains the redox dye tetrazolium violet, which turns from colorless to purple in the presence of respiration. The four isolated bacterial strains were isolated and selected from the 21 submitted to the toxicity test (above) according to their sensibility to NPs exposition. The CSS8, CSA28, CSA34, and CSA35 strains were grown in $\mathrm{LB}$ broth at $37^{\circ} \mathrm{C}$ for $12-18 \mathrm{~h}$ in a shaker incubator at $200 \mathrm{rpm}$. The bacterial suspension was centrifuged at $10,000 \mathrm{rpm}$ for $10 \mathrm{~min}$. and resuspended in $15 \mathrm{~mL}$ of sterile $0.85 \% \mathrm{NaCl}$ solution. The bacterial suspension was then adjusted to $\mathrm{OD}_{590 \mathrm{~nm}}=0.25$. A $150 \mu \mathrm{L}$ aliquot was inoculated into each well of the microplates. Plates were incubated at $27^{\circ} \mathrm{C}$, for $24 \mathrm{~h}$ and $72 \mathrm{~h}$.

2.8. Bacterial Cells Exposition to Nanoparticles. The strains CSS8, CSA28, CSA34, and CSA35 were cultured on LB broth at $37^{\circ} \mathrm{C}$ for $12-18 \mathrm{~h}$ in a shaker incubator at $200 \mathrm{rpm}$. The bacterial cells were recovered by centrifugation at 10,000 rpm for $10 \mathrm{~min}$ and then resuspended in $\mathrm{NaH}_{2} \mathrm{PO}_{4}$ buffer solution (25 mM, pH 7.4). The absorbance of the bacterial suspension was measured by a spectrophotometer and adjusted to $\mathrm{OD}_{620 \mathrm{~nm}}=0.1$. The isolates were treated with various concentrations $\left(0-160 \mathrm{mg} \cdot \mathrm{L}^{-1}\right)$ of CuONPs in $\mathrm{NaH}_{2} \mathrm{PO}_{4}$ buffer solution ( $25 \mathrm{mM}, \mathrm{pH} 7.4)$ and incubated at $37^{\circ} \mathrm{C}$ with shaking at $200 \mathrm{rpm}$. After $0.5,1,3,8$, and $24 \mathrm{~h}$, subsamples were taken and observed on scanning electron microscopy. At the end of experiments ( $24 \mathrm{~h}$ incubation) the ROS was determined (see below). All assays were performed in triplicate in Erlenmeyer flasks with a total volume of $50 \mathrm{~mL}$.

2.9. Biological Sample Preparation for SEM. The culture samples exposed to NPs and controls (not exposed) were analyzed by SEM. The samples preparation method was previously described by Maldonado et al. [28]. Briefly, subsample cultures were fixed in 3\% glutaraldehyde Milloning buffer phosphate ( $\mathrm{pH} \mathrm{7.3)} \mathrm{for} 4 \mathrm{~h}$ and washed two times in the same buffer. Afterwards, they were filtered on polycarbonate membrane (pore diameter $0.22 \mu \mathrm{m}$ ), fixed, and dehydrated increasing successively the ethanol concentration. All samples were mounted on metal stubs and coated with gold (Denton Vacuum Desk II). A Jeol JSM 7401F microscope was used to generate the images. The energy dispersive X-ray (EDX, Oxford Inca PentaFETX3) coupled to SEM was used for the elementary analysis.

2.10. Determination of Reactive Oxygen Species (ROS). Stock solutions of $10 \mu \mathrm{M} 2^{\prime}, 7^{\prime}$-dichlorodihydrofluorescein diacetate (DCFH-DA) and $2^{\prime}, 7^{\prime}$-dichlorodihydrofluorescein (DCFH) were prepared according to Luna-Velasco et al. [40]. A $2 \mathrm{~mL}$ subsample of the assay described above for bacterial cell exposition to nanoparticles was used for ROS test. Culture samples without exposure to NPs were used as controls. The bacterial cells of the subsample were recovered by centrifugation at $10,000 \mathrm{rpm}$ for $5 \mathrm{~min}$ and then resuspended in $\mathrm{NaH}_{2} \mathrm{PO}_{4}$ buffer solution $(25 \mathrm{mM}, \mathrm{pH} 7.4)$. Aliquots of $135 \mu \mathrm{L}$ were inoculated in black 96-well plates, with $15 \mu \mathrm{L}$ of $10 \mu \mathrm{M}$ DCF-DA. The black 96-well plates were incubated in darkness for $30 \mathrm{~min}$.; finally the fluorescence was measured at an excitation of $485 \mathrm{~nm}$ and emission wavelength of $535 \mathrm{~nm}$.

\section{Results and Discussion}

3.1. Chemical and Microbiological Characterization of Soil. The soil $\mathrm{pH}$ was close to neutral with high salt concentrations (Table 1). The crystal composition, analyzed by XRD, showed the presence of feldspars such as sanidine, Bytownite, and anorthoclase, as well as silicates such as silicon oxide and muscovite (Figure 2(a)).

The soil structure and morphology were observed by SEM micrograph; the texture was rough, forming flakes, and porous (Figure $2(\mathrm{~b})$ ). The chemical EDX analysis showed the presence of complementary elements such as $\mathrm{Al}, \mathrm{Si}$, $\mathrm{O}$, and $\mathrm{H}$, which form part of the components of feldspar (Figure 2(c)). The physicochemical characterization of the soil showed contradictory results: a low content of organic matter and salts, indicating that soil is poor, but a high cationic interchange capacity (CIC), suggesting a fertile soil.

The activity of the bacterial soil community was inferred from a shift of color media after an incubation time using Biolog EcoPlates test, showing the degradation of $22 / 31$ carbon sources tested (Table 2). Additionally, the hydrolysis of FDA was used to quantify this activity $(21.6 \pm$ $\left.0.021 \mu \mathrm{gFDA} \cdot \mathrm{mL}^{-1}\right)$. A few compounds of Biolog EcoPlates test were not used as carbon source: 3 carbohydrates, 1 amino acids, 2 carboxylic acids, 1 phenolic compound, and 2 polymers. Both the FDA hydrolysis and the Biolog EcoPlates analysis suggest that microbial populations have a high metabolic capacity. Thus, although the soil conditions limit the diversity of these samples, the present microorganisms are very active, explaining the soil fertility.

The CFU and MPN were used to estimate the cultivable microbial richness using different culture media. The highest bacterial counts were obtained with M9 medium $(8.6 \times$ $\left.10^{4} \mathrm{CFU} \cdot \mathrm{mL}^{-1}\right)$, followed by LB and YPS $\left(5.9 \times 10^{4}\right.$ and $5.2 \times 10^{4} \mathrm{CFU} \cdot \mathrm{mL}^{-1}$, resp.), below the values reported in 


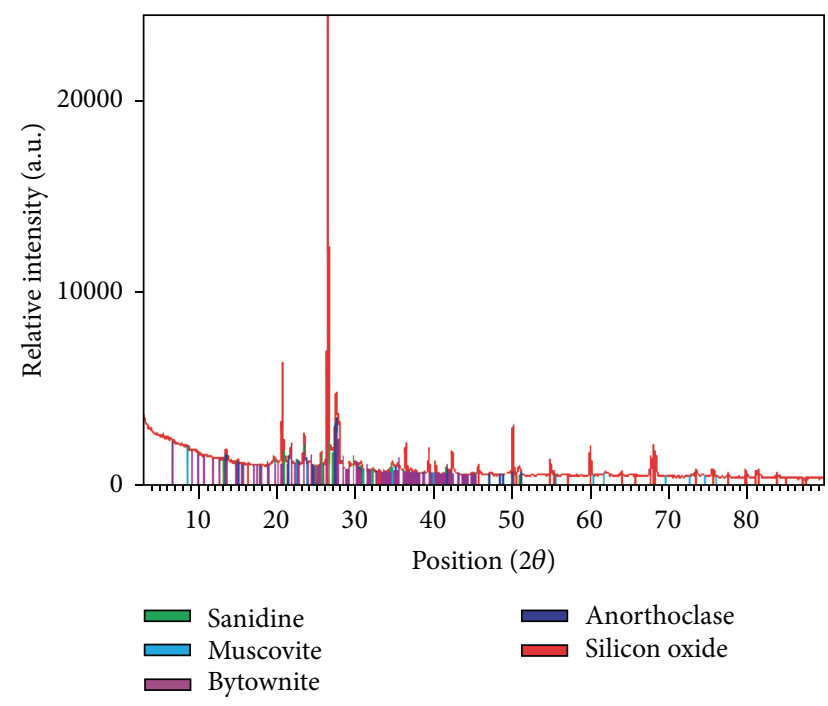

(a)

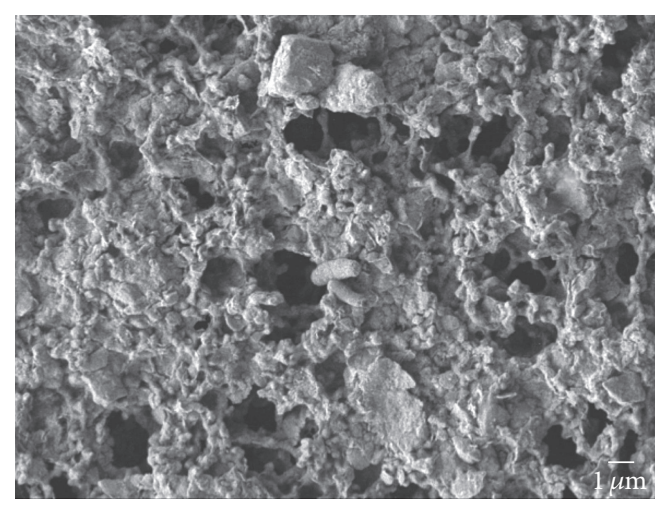

(b)

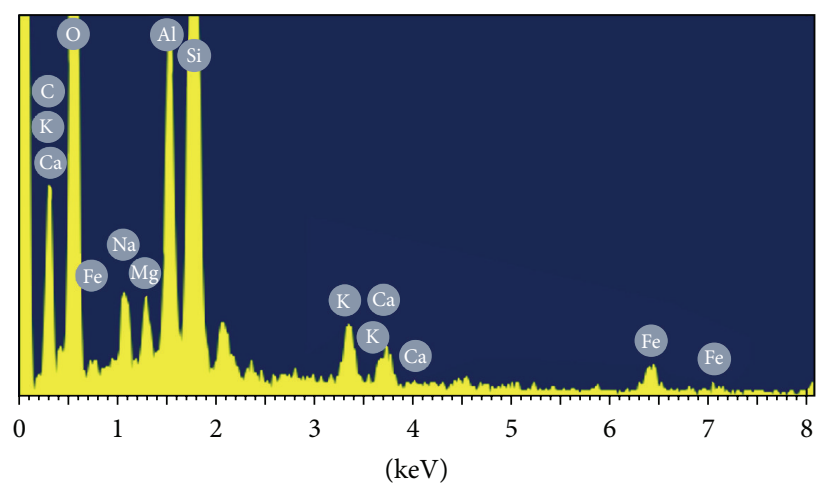

(c)

FIGURE 2: Characterization of soil: (a) XRD spectra of the crystallinity; (b) SEM image; and (c) EDX of the soil sample.

the literature for the bacterial recuperation by culture $\left(10^{8}\right.$ to $10^{10}$ bacterial per soil gram, [41]). The bacterial population size was estimated to be $2.1 \times 10^{5} \mathrm{cell} \cdot(\mathrm{g} \text { soil })^{-1}$ by MPN. The soil microbial communities are usually described as presenting high heterogeneity, which is usually related to the soil physical-chemical characteristics [41]. The results suggest that the cultivable bacterial communities of the studied soil do not require specific or complex nutrients. The utilization of the specific Actinobacteria media revealed that this bacterial group was scarcely represented in the studied soil (Table 1).

\subsection{Bacterial Strains Isolation. Fifty-six bacterial strains were} successfully isolated (Table 3 ) from this sample using 7 different culture media. The phylogenetic analysis, based on $16 \mathrm{~S}$ rRNA gene sequences, classified the isolated strains within 17 different OTUs (Figure 3). They were distributed into 3 classes: Bacilli (36 strains), Flavobacteria (2 strains), and Gammaproteobacteria (18 strains). According to their $16 \mathrm{~S}$ rRNA gene sequences, these strains are similar to bacterial strains associated with human disease, like Bacillus, Serratia, Enterobacter, and Pantoea species, or associated with biocontrol agents such as Brevibacillus laterosporus, Chryseobacterium indoltheticum, and Pantoea ananatis. However, more studies are necessary to verify the real source of these microorganisms. In addition, populations similar to Bacillus amyloliquefaciens and Pseudomonas putida were also found. Such species are reported as natural antifungal agents, which also can metabolize nitrogen and enhance the fertility.

Taking into account that the recovery of cultivable bacteria is usually very low, we just obtained a little part of the total bacterial diversity. Besides even when we use a specific media, we are unable to isolate typical soil groups like Agrobacterium or Actinobacteria. This result may be influenced by the soil characteristics, such as the low and limited amount of organic matter and great quantity of sand (71\%). The porosity and size of soil particles can produce constant shifts in the soil moisture, which does not allow growth or favors strong adhesion of microorganisms over particles [42]. Other factors that can inhibit or eliminate members of the original microflora are crop changes [43], the concentration of sugar, the osmolarity, the water activity, the $\mathrm{pH}$, and other environmental factors [44-47]. If any of these changes occur naturally or anthropogenically, the microorganisms that can 
TABLE 2: Pattern of 31 carbon substrates' utilization for sample soil and model strains CSS8, CSA28, CSA34, and CSA35.

\begin{tabular}{|c|c|c|c|c|c|}
\hline Enzyme activity & Soil sample & CSS8 & CSA28 & CSA34 & CSA35 \\
\hline Water & - & - & - & - & - \\
\hline$\beta$-Methyl-D-glucoside & - & + & + & + & + \\
\hline D-Galactonic acid $\gamma$-lactone & + & + & + & + & + \\
\hline L-Arginine & + & + & + & + & + \\
\hline Pyruvic acid methyl ester & + & + & + & + & + \\
\hline D-Xylose & - & + & + & + & + \\
\hline D-Galacturonic acid & - & + & + & + & + \\
\hline L-Asparagine & + & + & + & + & + \\
\hline Tween 40 & + & + & + & + & + \\
\hline I-Erythritol & + & + & + & + & + \\
\hline 2-Hydroxy benzoic acid & - & - & + & + & - \\
\hline L-Phenylalanine & - & + & + & + & + \\
\hline Tween 80 & + & + & + & + & + \\
\hline D-Mannitol & + & + & + & + & + \\
\hline 4-Hydroxy benzoic acid & + & - & + & + & + \\
\hline L-Serine & + & + & + & + & + \\
\hline$\alpha$-Cyclodextrin & - & + & + & + & + \\
\hline N-Acetyl-D-glucosamine & + & + & + & + & + \\
\hline$\gamma$-Hydroxybutyric acid & + & + & + & + & + \\
\hline L-Threonine & + & + & + & + & + \\
\hline Glycogen & - & + & + & + & + \\
\hline D-Glucoaminic acid & + & + & + & + & + \\
\hline Itaconic acid & + & + & + & + & + \\
\hline Glycil_L_glutamic acid & + & + & + & + & + \\
\hline D-Cellobiose & + & + & + & + & + \\
\hline Glucose-1-phosphate & + & + & + & + & + \\
\hline$\alpha$-Ketobutyric acid & - & + & + & + & + \\
\hline Phenylethylamine & + & + & + & + & + \\
\hline$\alpha$-D-Lactose & + & + & + & + & + \\
\hline D,L- $\alpha$-Glycerol phosphate & - & + & + & + & + \\
\hline D-Mallic acid & + & - & + & + & + \\
\hline Putrescine & + & + & + & + & + \\
\hline
\end{tabular}

survive under these changes probably develop adaptive characteristics.

3.3. Characterization of CuONPs. The method used to synthesize the CuONPs was the same described by Lanje et al. [38], with the difference that we obtained spherical instead of rectangular NPs. The SEM and TEM micrographs show spherical shape. Differences in the morphology due to shift in temperature were reported for $\mathrm{CuO}$ nanorods synthesis by Gao et al. [48]. They obtained two different structures when the nanorods are synthetized at room temperature or $100^{\circ} \mathrm{C}$. The particle sizes in SEM micrograph were in the range from 10 to $17 \mathrm{~nm}$ and the SEM-EDX profile indicated that the preparation did not contain synthesis waste and NPs composition is only of copper and oxygen (Figures 4(a) and 4(b)). Zhang et al. [49] reported that the initial concentration might affect the NPs formation. They propose the formation of nanoparticles in solution in two stages, first the generation of copper nuclei and then the growing up of these nuclei for the formation of NPs. When the reactant concentration is high the number of nuclei increases in the solution, consequently the NPs sizes are incremented resulting in agglomerates. UV-Vis spectra of the synthesized CuONPs showed the band-edge emission peak at $280 \mathrm{~nm}$ (Figure 4(c)). We also used X-ray analysis to identify the crystalline phase; this analysis revealed the presence of $\mathrm{CuO}$ only (Figure 4(d)).

\subsection{Exposure of Bacterial Cells to CuONPs and ROS Genera-} tion. We used a liquid microculture $(200 \mu \mathrm{L})$ for the screening of bacterial strains sensitive to CuONPs (Table 4). Among twenty-one strains tested, eleven showed no resistance to CuONPs, while the strains CSR19A, CSL10A, and CSMB13A exhibited the highest resistances $\left(17,22.5\right.$, and $25 \mathrm{mg} \cdot \mathrm{L}^{-1}$, resp.). Besides their sensibility to CuONPs exposition test and the originality for their use as toxicity model to the studied NP, we also considered their importance in the contribution in soil microbial community and biogeochemical cycles. 


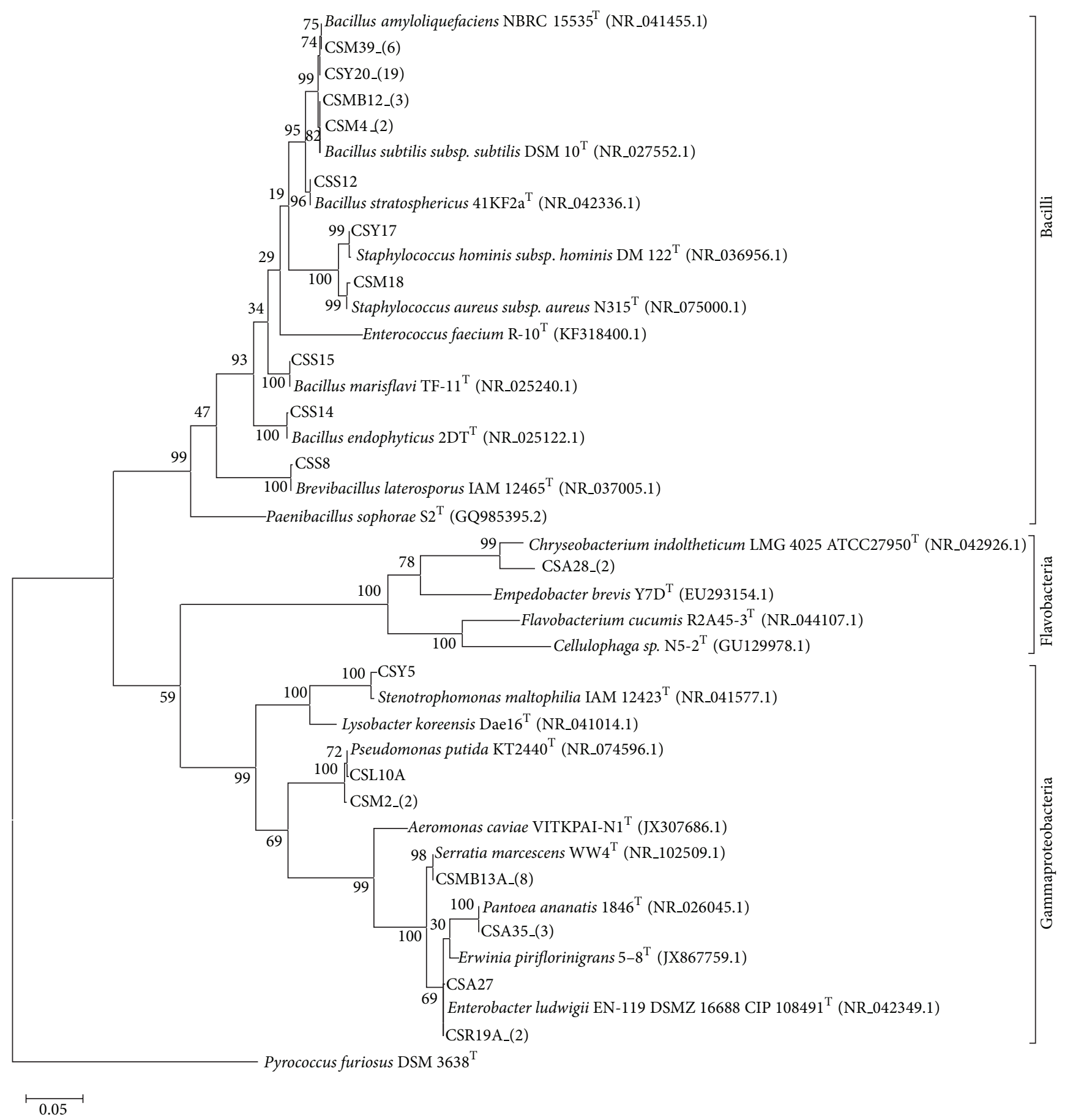

Figure 3: Phylogenetic tree based on 16S rRNA gene sequences of isolated strains showing the cultivable bacterial diversity of the soil.

The CSS8 (99\% similarity to Brevibacillus laterosporus), CSA28 (99\% similarity to Chryseobacterium indoltheticum), CSA34, and CSA35 (both with 99\% similarity to Pantoea ananatis) were selected as bacterial models for the determination of damages caused by CuONPs. Their metabolic capacities are presented Table 2. The CSS8 strain was capable to use 28/31 (except 2 phenolic compounds and 1 carboxylic acid); the CSA28 and CSA34 strains were able to use all carbon sources and the CSA35 strain degraded 30/31 substrates (except 2hydroxy benzoic acid). These strains showed higher capacities for carbon source utilization than that observed for the whole bacterial community. This difference may be explained by the fact that bacterial expression depends on complex bacterial/bacterial interactions in microbial communities.

The selected strains were individually exposed to CuONPs in phosphate buffer ( $25 \mathrm{mM}, \mathrm{pH} 7.4)$ and subsamples were 


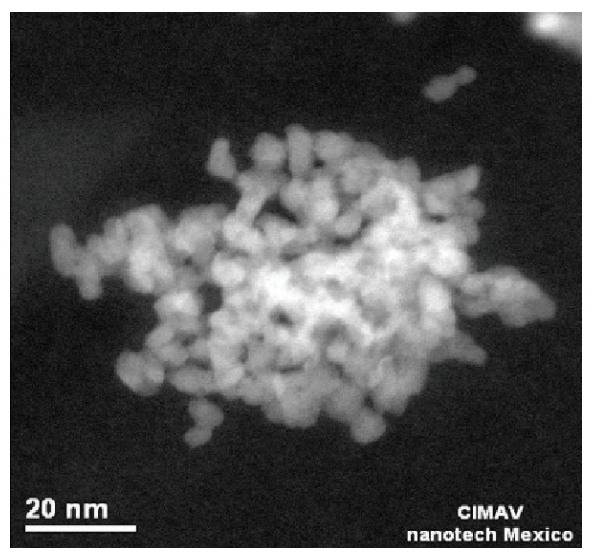

(a)

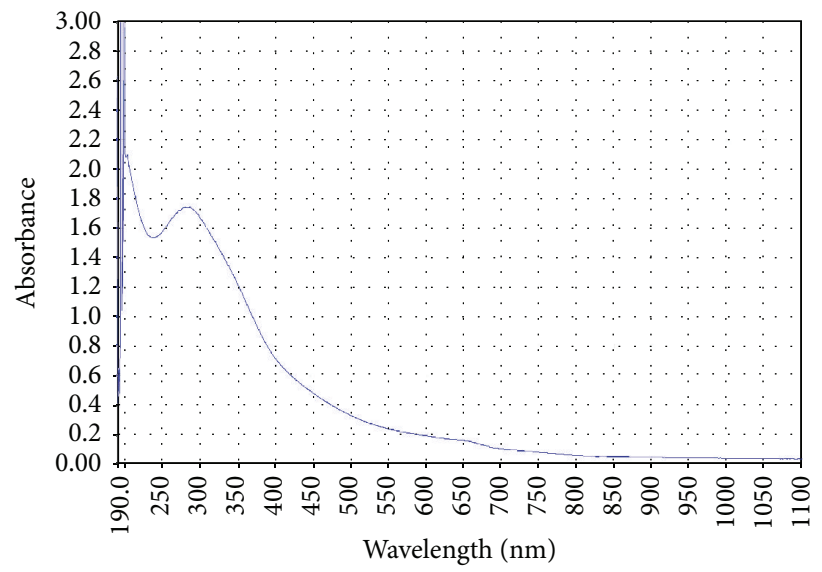

(c)

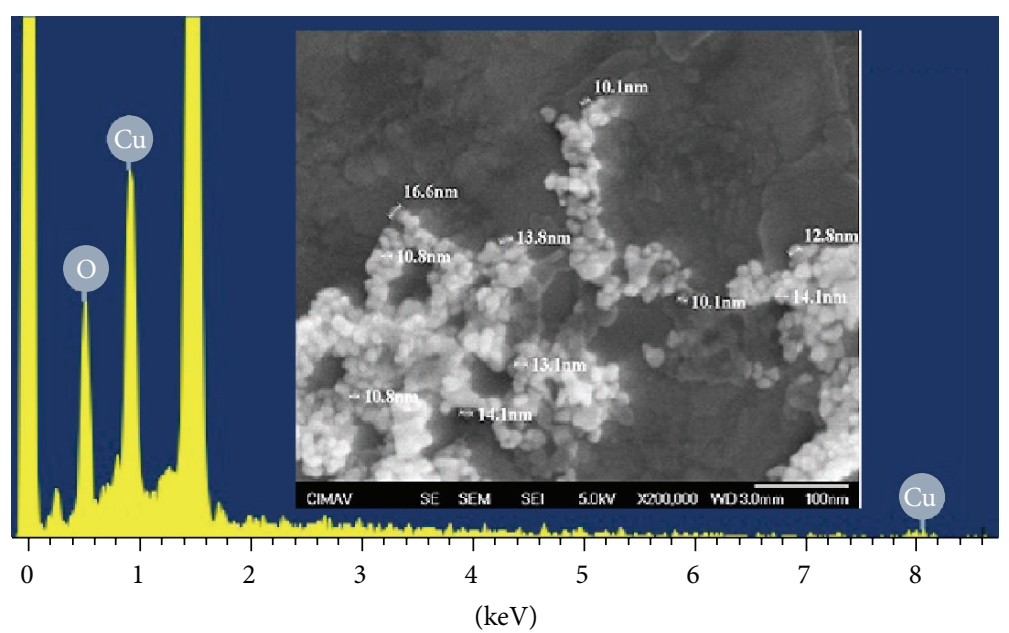

(b)

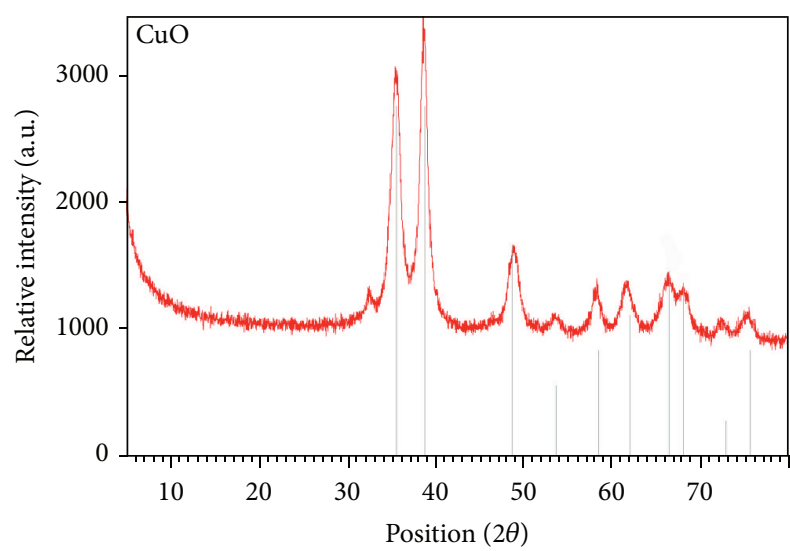

(d)

FIGURE 4: Characterization of CuONPs: (a) TEM micrograph; (b) SEM micrograph showing the shape and the particle size estimation with the superposed SEM-EDX spectrum indicating the composition; (c) UV-visible spectrum; and (d) X-ray spectra.

observed by SEM. The SEM micrographs showed different kind of damage on the cell membrane in the 4 strains when they were exposed above $160 \mathrm{mg} \cdot \mathrm{L}^{-1}$ of CuONPs. Changes on the shape were observed, from normal shape rod to bigger, stretched, and apparently empty cells and even to lysed cells (Figures 5(b) and 5(k)). Other observed effects were the cavities and pits formation over cells membrane (Figures 5(e) and 5(h)). These modifications were not observed in control rod cells (not exposed to CuONPs) (Figures 5(a), 5(d), 5(g), and $5(\mathrm{j}))$. Although the exact mechanisms of toxicity are not completely understood, it is probable that the toxicity generated by CuONPs on CSA28 and CSA34 strains is due to NPs solubilization that produce $\mathrm{Cu}^{2+}$ ions. At low concentrations copper is a micronutrient essential for cell metabolism. It is required as a cofactor in multiple proteins, it takes part in redox reactions such as electron transport, oxidative respiration, or the denitrification process and, in some cases, it is also a structural element [50]. However, despite the critical role of $\mathrm{Cu}$ in a wide array of biological processes, the excess of $\mathrm{Cu}$ could be toxic [51]. We also observed the adhesion of $\mathrm{Cu}$ over cells membrane in the SEM-EDX profiles
(Figures 5(c), 5(f), 5(i), and 5(l)) suggesting some interactions of $\mathrm{Cu}$ directly to the cell membrane. The CuONPs-cell interactions due to opposite electrical charges carry out a reduction reaction in the bacterial cell wall, which causes adhesion and bioactivity conducted by electrostatic forces [52-55]. The wall cell of Gram-negative bacteria is made mainly of polysaccharides and the negative charge resulting from groups such as carboxylate, phosphate, hydroxyl, amine, and sulfhydryl has an important role as membrane active sites $[56,57]$. The interactions of these groups with $\mathrm{Cu}^{2+}$ ions produce denaturation and alteration of membrane proteins [58].

Oxidative stress is normally used to evaluate the toxicity of several compounds including those caused by metallic nanoparticles [8]. Diverse reactive molecules can be produced during the oxidative stress such as nitric oxide (NO), peroxynitrite $\left(\mathrm{ONOO}^{-}\right)$, superoxide $\left(\mathrm{O}_{2}{ }^{--}\right)$, hydrogen peroxide $\left(\mathrm{H}_{2} \mathrm{O}_{2}\right)$, hypochlorous acid $(\mathrm{HOCl})$, and hydroxyl radical $\left(\mathrm{OH}^{*}\right)$. The fluorescent probe traditionally used to identify ROS is $2^{\prime}, 7^{\prime}$-dichlorodihydrofluorescein diacetate (DCFHDA), which reflects the overall oxidative status of the cell. 
TABLE 3: GenBank accession numbers of bacterial strains isolated from agricultural soil.

\begin{tabular}{|c|c|}
\hline Isolated strain & GenBank accession number \\
\hline CSM39 & KM091676 \\
\hline CSL6 & KM091677 \\
\hline CSL21 & KM091678 \\
\hline CSM40 & KM091679 \\
\hline CSM42 & KM091680 \\
\hline CSL44 & KM091681 \\
\hline CSY20 & KM091682 \\
\hline CSM30 & KM091683 \\
\hline CSM31 & KM091684 \\
\hline CSA25 & KM091685 \\
\hline CSA26 & KM091686 \\
\hline CSL22 & KM091687 \\
\hline CSA23 & KM091688 \\
\hline CSY19 & KM091689 \\
\hline CSL16 & KM091690 \\
\hline CSS13 & KM091691 \\
\hline CSM11 & KM091692 \\
\hline CSS9 & KM091693 \\
\hline CSS7 & KM091694 \\
\hline CSM38 & KM091695 \\
\hline CSM32 & KM091696 \\
\hline CSA36 & KM091697 \\
\hline CSM33 & KM091698 \\
\hline CSM41 & KM091699 \\
\hline CSMB12 & KM091700 \\
\hline CSY1 & KM091701 \\
\hline CSMB13B & KM091702 \\
\hline CSM4 & KM091703 \\
\hline CSM5 & KM091704 \\
\hline CSS12 & KM091705 \\
\hline CSY17 & KM091706 \\
\hline CSM18 & KM091707 \\
\hline CSS15 & KM091708 \\
\hline CSS14 & KM091709 \\
\hline CSS8 & KM091710 \\
\hline CSL43 & KM091711 \\
\hline CSY5 & KM091712 \\
\hline CSL10A & KM091713 \\
\hline CSM2 & KM091714 \\
\hline CSM10 & KM091715 \\
\hline CSMB13A & KM091716 \\
\hline CSY6A & KM091717 \\
\hline CSMB16 & KM091718 \\
\hline CSMB14A & KM091719 \\
\hline CSY2 & KM091720 \\
\hline CSY6B & KM091721 \\
\hline CSY7 & KM091722 \\
\hline CSL11 & KM091723 \\
\hline CSA35 & KM091724 \\
\hline CSA34 & KM091725 \\
\hline
\end{tabular}

TABLE 3: Continued.

\begin{tabular}{lc}
\hline Isolated strain & GenBank accession number \\
\hline CSA37 & KM091726 \\
CSA27 & KM091727 \\
CSR19A & KM091728 \\
CSR19B & KM091729 \\
\hline
\end{tabular}

TABle 4: Maximum concentration of CuONPs in which each bacterial isolate can survive.

\begin{tabular}{lc}
\hline $\begin{array}{l}\text { Concentration } \\
\text { CuONPs } \\
\left(\mathrm{mg} \cdot \mathrm{L}^{-1}\right)\end{array}$ & Strains \\
\hline 0 & $\begin{array}{c}\text { CSY17, CSM18, CSS15, CSS14, CSS8 } \\
\text { CSY5, CSM2, CSA34 }{ }^{*}, \text { CSA35 }{ }^{*}, \text { CSM39B }\end{array}$ \\
1 & CSS12 \\
2 & CSMB12, CSM4, CSA27 \\
4 & CSY20 \\
17 & CSR19A \\
22.5 & CSL10A \\
25 & CSMB13A \\
\hline
\end{tabular}

${ }^{*}$ Strains selected for evaluating the specific damage caused by CuONPs exposition.

However, it is not applicable to individual ROS compounds detection. By using this compound, we did not observe any increase in the ROS production comparing the control strains (without NPs) with the strains exposed to CuONPs. In fact, a slight decrease in the ROS activities is observed for CSS8, CSA34, and CSA35 strains whereas for CSA28 strain the decrease is until 6-fold less (Figure 6).

Ours results are comparable to those obtained by Cui et al., [59] working with Escherichia coli and gold NPs (AuNPs). They found that the AuNPs did not induce increase in cellular ROS but, instead, led to a decrease after $4 \mathrm{~h}$ of exposition. Meanwhile there are same controversial results in the scientific literature about the mechanism of oxidative stress generated by NPs. For example, Dasari et al. [60] evaluated the toxicity mechanism of several NPs with E. coli. For titanium NPs $\left(\mathrm{TiO}_{2} \mathrm{NPs}\right)$ and zinc NPs (ZnONPs) they found an increase in the amount of ROS while for CuONPs and cobalt oxide NPs $\left(\mathrm{Co}_{3} \mathrm{O}_{4} \mathrm{NPs}\right)$ any effect was observed. In other work, Dimkpa et al. [53] evaluated the toxicity of commercial CuONPs in the pathogenic bacteria Pseudomonas chlororaphis O6. They observed an accumulation of intracellular ROS with concentrations higher to $500 \mathrm{ppm}$ of $\mathrm{CuONPs}$ whereas lower concentrations did not induce ROS generation. Furthermore, several studies have reported the increased of ROS activities when cells are exposed to NPs, for example, Lee et al. [61], Gunawan et al. [62], and Rastogi et al. [63]. The ROS levels increment was produced when E. coli was exposed to CuONPs [62] and AgNPs [61]. Similar effects are shown for Staphylococcus aureus 49834, E. coli 25922, and Pseudomonas aeruginosa 27853 in presence of AgNPs [61, 63].

It is known that denitrifying bacteria can produce NO endogenously as an intermediate from the sequential reaction 


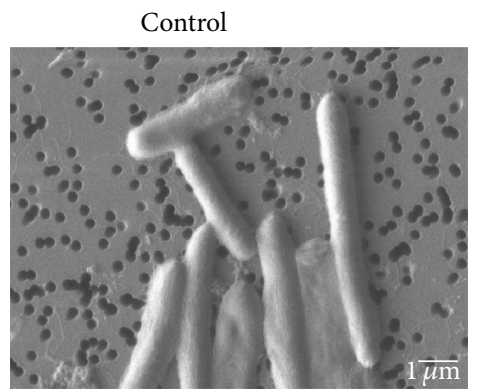

(a)

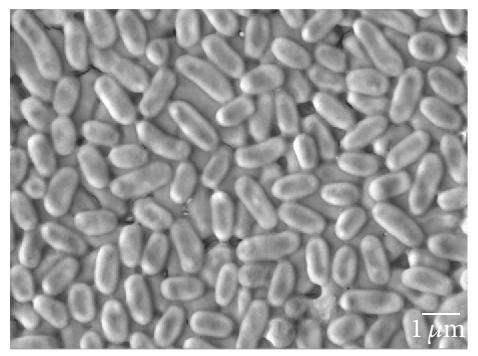

(d)

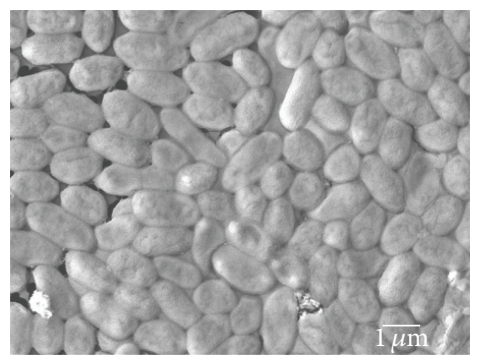

(g)

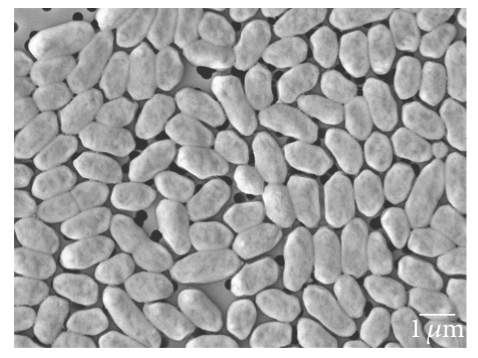

(j)
CuONPs

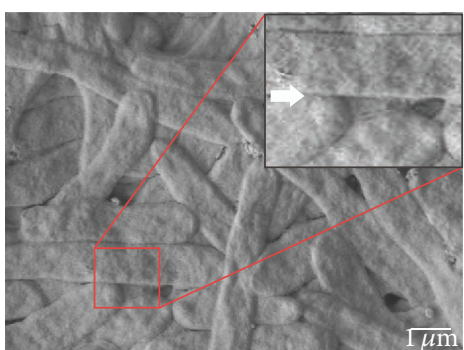

(b)

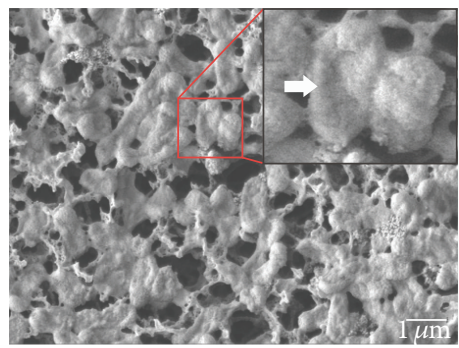

(e)

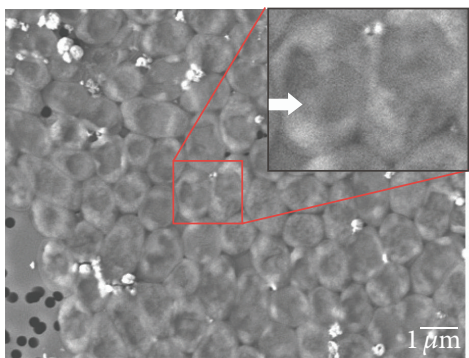

(h)

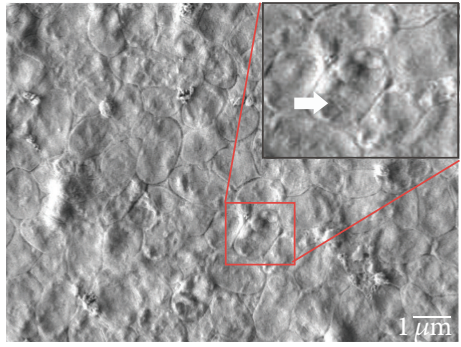

(k)

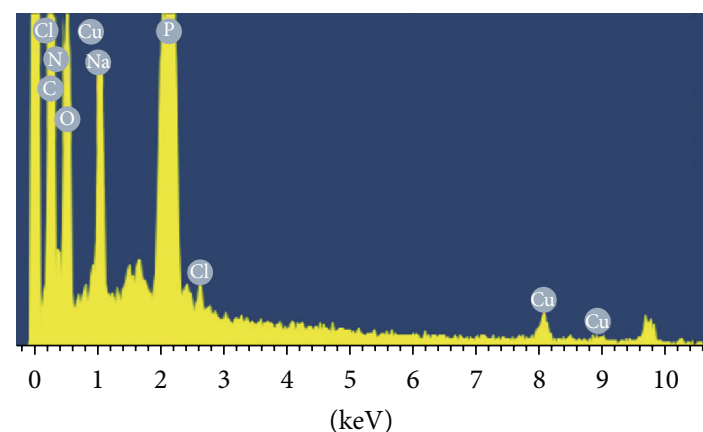

(c)

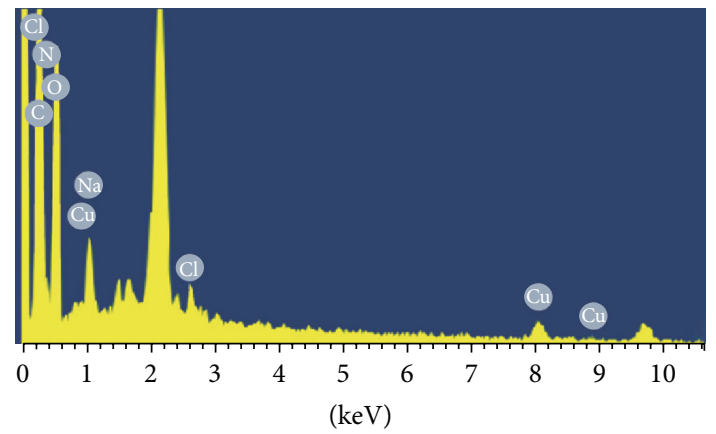

(f)

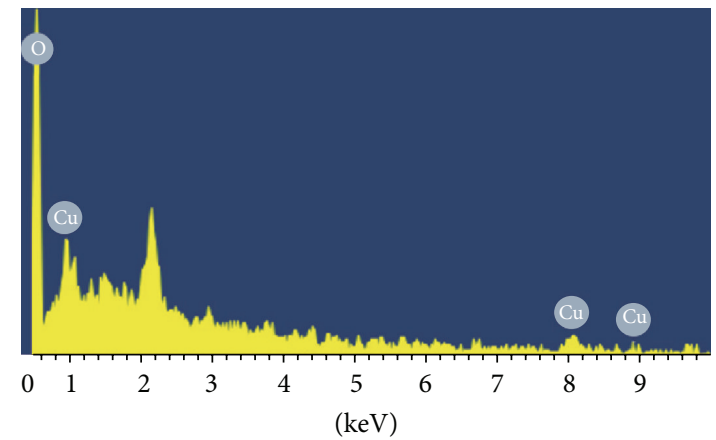

(i)

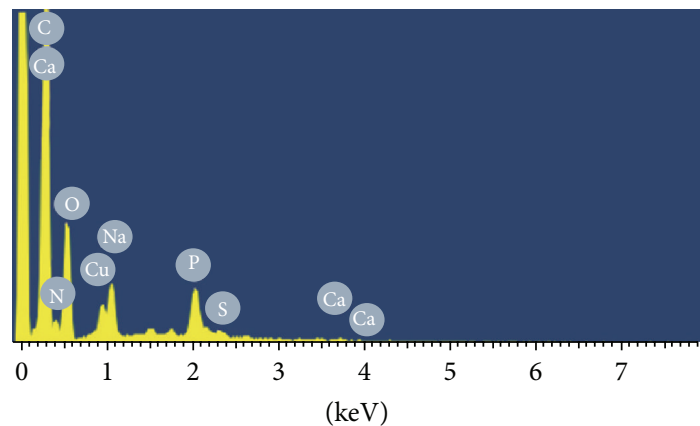

(l)

FIGURE 5: Scanning electron microscopy (SEM) of CSS8, CSA28, CSA34, and CSA35 cells treated with CuONPs (b, e, h, and $\mathrm{k}$ ) and respective controls (a, d, g, and j); SEM-EDX spectrum for the surface of a cell (c, f, i, and l). 


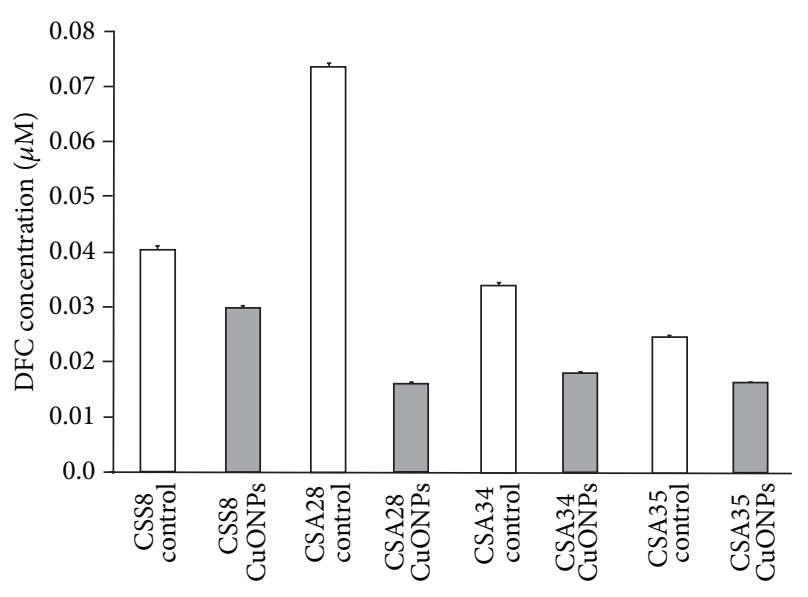

FIGURE 6: ROS activities in CSS8, CSA28, CSA34, and CSA35 model strains.

of nitrate to dinitrogen [64]. The SEM micrographs of CSS8 and CSA35 strains show different damage generated from $\mathrm{CuONPs}$ such as membrane collapse, bleb formation, and cellular debris, leading to the loss of the bacterial membrane integrity, irreversible cell damage, or cell death (Figure 5). Considering that the model bacterial strains selected on this study are phylogenetically related to denitrifying bacteria, it is possible that the membrane damage observed by SEM could be caused by the presence of nitrogen reactive species such as nitric oxide (NO). In the case of our selected strains, the cytotoxicity could be associated with damage in proteins that use copper like cofactor such as nitrous oxide reductase $\left(\mathrm{N}_{2} \mathrm{OR}\right)$, nitric oxide reductase (NOR), and cytochrome C. These proteins are also involved in the denitrification process, resulting in overproduction of reactive nitrogen and oxygen species. Several reports have associated the presence of NPs with the increase of expression of these proteins and the malfunction of metal binding enzymes [65]. Besides, other reports analyzing the effect produced over the cell membrane by the exposition to NO in $P$. aeruginosa and $E$. coli strains [65-69] showed similar damage to those observed in this study. However, further studies are required to verify the cytotoxic mechanism.

\section{Conclusions}

Several pure culture studies have shown that the bacterial interaction with NPs may produce cytotoxicity in different parts of the cell, such as membrane disorganization, denaturation of thiol containing membrane proteins, DNA damage [70-72], and oxidation beyond ROS production [25]. We showed here that CuONPs are very toxic for native soil bacteria. The CuONPs interaction with cell wall components modified cell morphology and affected the function of membrane proteins. We thus considered that the cytotoxicity against the model strains could be attributed mainly to oxide-reduction reactions over the cell membrane and the generation of nitrogen reactive species. These results point out that wild strains, like those isolated here, can indeed be affected by nanocontaminants. Thus, it is pivotal to intensify the studies on the damage and toxicity of nanomaterials to living cells and microbial communities in order to establish fair regulations for the discharge of NPs in the environment, directly or through the waste of products containing them.

\section{Conflict of Interests}

The authors declare that there is no conflict of interests regarding the publication of this paper.

\section{Acknowledgments}

This work was supported by grants from CONACyTCNPq MOD.ORD.44/2012 (42-205000-CB3O040113), Universidad de Guanajuato-DAIP (0195/2013), and Sandra I. Concha-Guerrero received a fellowship from CONACyT. The authors acknowledge the Regional Platform for Environmental Microbiology PREMICE supported by the Aquitaine Regional Government Council and the urban community of Pau-Pyrénées (France). They are also indebted to Wilber Antunez Flores (Department of Nanotechnology, NANOTECH, CIMAV, Chihuahua, CHIH, México) and Luis Antonio Soto Plascencia (CIMAV, Chihuahua, CHIH, México).

\section{References}

[1] A. D. Maynard, Nanotechnology: A Research Strategy for Addressing Risk, Woodrow Wilson International Center for Scholars, Washington, DC, USA, 2006.

[2] F. Gottschalk, T. Sonderer, R. W. Scholz, and B. Nowack, "Modeled environmental concentrations of engineered nanomaterials $\left(\mathrm{TiO}_{2}, \mathrm{ZnO}, \mathrm{Ag}, \mathrm{CNT}\right.$, fullerenes) for different regions," Environmental Science and Technology, vol. 43, no. 24, pp. 92169222, 2009.

[3] S. J. Klaine, P. J. J. Alvarez, G. E. Batley et al., "Nanomaterials in the environment: behavior, fate, bioavailability, and effects," Environmental Toxicology and Chemistry, vol. 27, no. 9, pp. 18251851, 2008.

[4] P. A. Maurice and M. F. Hochella, "Nanoscale particles and processes: a new dimension in soil science," Advances in Agronomy, vol. 100, pp. 123-153, 2009.

[5] K. Tiede, M. Hassellöv, E. Breitbarth, Q. Chaudhry, and A. B. A. Boxall, "Considerations for environmental fate and ecotoxicity testing to support environmental risk assessments for engineered nanoparticles," Journal of Chromatography A, vol. 1216, no. 3, pp. 503-509, 2009.

[6] L. Vittori Antisari, S. Carbone, A. Gatti, G. Vianello, and P. Nannipieri, "Toxicity of metal oxide $\left(\mathrm{CeO}_{2}, \mathrm{Fe}_{3} \mathrm{O}_{4}, \mathrm{SnO}_{2}\right)$ engineered nanoparticles on soil microbial biomass and their distribution in soil," Soil Biology and Biochemistry, vol. 60, pp. 87-94, 2013.

[7] M. C. Newman and M. A. Unger, Fundamentals of Ecotoxicology, Lewis Publishing, Albany, Ga, USA, 2nd edition, 2003.

[8] O. Choi and Z. Hu, "Role of reactive oxygen species in determining nitrification inhibition by metallic/oxide nanoparticles," Journal of Environmental Engineering, vol. 135, no. 12, pp. 13651370, 2009.

[9] H. Schwegmann and F. H. Frimmel, "Nanoparticles: interaction with microorganisms," in Nanoparticles in the Water Cycle, F. H. Frimmel and R. Niessner, Eds., Springer, Berlin, Germany, 2010. 
[10] D. Y. Lyon, A. Thill, J. Rose, and P. J. J. Alvarez, "Alvarez, ecotoxicological impact of nanomaterials," in Environmental Nanotechnology: Application and Impacts of Nanomaterials, $\mathrm{M}$. R. Wiesner and J. Y. Bottero, Eds., McGraw-Hill, New York, NY, USA, 2007.

[11] J. Ramyadevi, K. Jeyasubramanian, A. Marikani, G. Rajakumar, and A. A. Rahuman, "Synthesis and antimicrobial activity of copper nanoparticles," Materials Letters, vol. 71, pp. 114-116, 2012.

[12] E. Baath, "Effects of heavy metals in soil on microbial processes and populations," Water, Air, and Soil Pollution, vol. 47, no. 3-4, pp. 335-379, 1989.

[13] P. C. Brookes, "The use of microbial parameters in monitoring soil pollution by heavy metals," Biology and Fertility of Soils, vol. 19, no. 4, pp. 269-279, 1995.

[14] C. Viti, D. Quaranta, R. de Philippis et al., "Characterizing cultivable soil microbial communities from copper fungicideamended olive orchard and vineyard soils," World Journal of Microbiology and Biotechnology, vol. 24, no. 3, pp. 309-318, 2008.

[15] D. Fernández-Calviño, A. Martín, M. Arias-Estévez, E. Bååth, and M. Díaz-Raviña, "Microbial community structure of vineyard soils with different $\mathrm{pH}$ and copper content," Applied Soil Ecology, vol. 46, no. 2, pp. 276-282, 2010.

[16] G. Ren, D. Hu, E. W. C. Cheng, M. A. Vargas-Reus, P. Reip, and R. P. Allaker, "Characterization of copper oxide nanoparticles for antimicrobial applications," International Journal of Antimicrobial Agents, vol. 33, pp. 587-590, 2009.

[17] Y.-W. Baek and Y.-J. An, "Microbial toxicity of metal oxide nanoparticles $\left(\mathrm{CuO}, \mathrm{NiO}, \mathrm{ZnO}\right.$, and $\left.\mathrm{Sb}_{2} \mathrm{O}_{3}\right)$ to Escherichia coli, Bacillus subtilis, and Streptococcus aureus," Science of the Total Environment, vol. 409, no. 8, pp. 1603-1608, 2011.

[18] O. Bondarenko, A. Ivask, A. Käkinen, and A. Kahru, "Subtoxic effects of $\mathrm{CuO}$ nanoparticles on bacteria: kinetics, role of $\mathrm{Cu}$ ions and possible mechanisms of action," Environmental Pollution, vol. 169, pp. 81-89, 2012.

[19] S. Jadhav, S. Gaikwad, M. Nimse, and A. Rajbhoj, "Copper oxide nanoparticles: synthesis, characterization and their antibacterial activity," Journal of Cluster Science, vol. 22, no. 2, pp. 121-129, 2011.

[20] A. M. Studer, L. K. Limbach, L. Van Duc et al., "Nanoparticle cytotoxicity depends on intracellular solubility: comparison of stabilized copper metal and degradable copper oxide nanoparticles," Toxicology Letters, vol. 197, no. 3, pp. 169-174, 2010.

[21] J. S. Kim, E. Kuk, K. N. Yu et al., "Antimicrobial effects of silver nanoparticles," Nanomedicine, vol. 3, no. 1, pp. 95-101, 2007.

[22] J. H. Niazi and M. B. Gu, "Toxicity of metallic nanoparticles in microorganism - a review," in Atmospheric and Biological Environmental Monitoring, Y. J. Kim, Ed., Springer Science+Business Media B.V., 2009.

[23] S. He, Y. Feng, H. Ren, Y. Zhang, N. Gu, and X. Lin, "The impact of iron oxide magnetic nanoparticles on the soil bacterial community," Journal of Soils and Sediments, vol. 11, no. 8, pp. 1408-1417, 2011.

[24] C. O. Dimkpa, J. E. McLean, D. E. Latta et al., "CuO and $\mathrm{ZnO}$ nanoparticles: phytotoxicity, metal speciation, and induction of oxidative stress in sand-grown wheat," Journal of Nanoparticle Research, vol. 14, no. 9, article 1125, 2012.

[25] Y. Ge, J. P. Schimel, and P. A. Holdena, "Identification of soil bacteria susceptible to $\mathrm{TiO}_{2}$ and $\mathrm{ZnO}$ nanoparticles," Applied and Environmental Microbiology, vol. 78, no. 18, pp. 6749-6758, 2012.
[26] V. Torsvik and L. Øvreås, "Microbial diversity and function in soil: from genes to ecosystems," Current Opinion in Microbiology, vol. 5, no. 3, pp. 240-245, 2002.

[27] R. Dinesh, M. Anandaraj, V. Srinivasan, and S. Hamza, "Engineered nanoparticles in the soil and their potential implications to microbial activity," Geoderma, vol. 173-174, pp. 19-27, 2012.

[28] J. Maldonado, A. Solé, Z. M. Puyen, and I. Esteve, "Selection of bioindicators to detect lead pollution in Ebro delta microbial mats, using high-resolution microscopic techniques," Aquatic Toxicology, vol. 104, no. 1-2, pp. 135-144, 2011.

[29] C.-N. Lok, C.-M. Ho, R. Chen et al., "Proteomic analysis of the mode of antibacterial action of silver nanoparticles," Journal of Proteome Research, vol. 5, no. 4, pp. 916-924, 2006.

[30] P. F. Weaver, J. D. Wall, and H. Gest, "Characterization of Rhodopseudomonas capsulata," Archives of Microbiology, vol. 105, no. 3, pp. 207-216, 1975.

[31] J. L. Oblinger and J. A. Koburger, "Understanding and teaching the most probable number technque," Journal of Milk and Food Technology, vol. 38, no. 9, pp. 540-545, 1975.

[32] D. J. Reasoner and E. E. Geldreich, "A new medium for the enumeration and subculture of bacteria from potable water," Applied and Environmental Microbiology, vol. 49, no. 1, pp. 1-7, 1985.

[33] G. Adam and H. Duncan, "Development of a sensitive and rapid method for the measurement of total microbial activity using fluorescein diacetate (FDA) in a range of soils," Soil Biology and Biochemistry, vol. 33, no. 7-8, pp. 943-951, 2001.

[34] C. Floch, A.-C. Chevremont, K. Joanico, Y. Capowiez, and S. Criquet, "Indicators of pesticide contamination: soil enzyme compared to functional diversity of bacterial communities via Biolog Ecoplates," European Journal of Soil Biology, vol. 47, no. 4, pp. 256-263, 2011.

[35] D. J. Lane, "rRNA sequencing," in Nucleic Acid Techniques in Bacterial Systematic, G. M. E. Stachenbradt, Ed., pp. 115-175, Wiley, Chichester, UK, 1991.

[36] W. G. Weisburg, S. M. Barns, D. A. Pelletier, and D. J. Lane, "16S ribosomal DNA amplification for phylogenetic study," Journal of Bacteriology, vol. 173, no. 2, pp. 697-703, 1991.

[37] S. Kumar, K. Tamura, and M. Nei, "MEGA3: integrated software for molecular evolutionary genetics analysis and sequence alignment," Briefings in Bioinformatics, vol. 5, no. 2, pp. 150-163, 2004.

[38] A. S. Lanje, S. J. Sharma, R. B. Pode, and R. S. Ningthoujam, "Synthesis and optical characterization of copper oxide nanoparticles," Advances in Applied Science Research, vol. 1, no. 2, pp. 36-40, 2010.

[39] J.-C. Palomino, A. Martin, M. Camacho, H. Guerra, J. Swings, and F. Portaels, "Resazurin microtiter assay plate: simple and inexpensive method for detection of drug resistance in Mycobacterium tuberculosis," Antimicrobial Agents and Chemotherapy, vol. 46, no. 8, pp. 2720-2722, 2002.

[40] A. Luna-Velasco, J. A. Field, A. Cobo-Curiel, and R. SierraAlvarez, "Inorganic nanoparticles enhance the production of reactive oxygen species (ROS) during the autoxidation of 1-3,4dihydroxyphenylalanine (1-dopa)," Chemosphere, vol. 85, no. 1, pp. 19-25, 2011.

[41] R. L. Tate, Soil Microbiology, John Wiley \& Sons, New York, NY, USA, 2000.

[42] H. Hohl and A. Varma, "Soil: the living matrix," in Soil Heavy Metals, vol. 19 of Soil Biology, pp. 1-18, Springer, Berlin, Germany, 2010. 
[43] G. Chaer, M. Fernandes, D. Myrold, and P. Bottomley, "Comparative resistance and resilience of soil microbial communities and enzyme activities in adjacent native forest and agricultural soils," Microbial Ecology, vol. 58, no. 2, pp. 414-424, 2009.

[44] A. D. Brown, Microbial Water Strees Physiology-Principles and Perspectives, John Wiley \& Sons, Chichester, UK, 1990.

[45] J. E. Hallsworth, Y. Nomura, and M. Iwahara, "Ethanol-induced water stress and fungal growth," Journal of Fermentation and Bioengineering, vol. 86, no. 5, pp. 451-456, 1998.

[46] P. Bhaganna, R. J. M. Volkers, A. N. W. Bell et al., "Hydrophobic substances induce water stress in microbial cells," Microbial Biotechnology, vol. 3, no. 6, pp. 701-716, 2010.

[47] J. A. Cray, A. N. W. Bell, P. Bhaganna, A. Y. Mswaka, D. J. Timson, and J. E. Hallsworth, "The biology of habitat dominance; can microbes behave as weeds?" Microbial Biotechnology, vol. 6, no. 5, pp. 453-492, 2013.

[48] X. P. Gao, J. L. Bao, G. L. Pan et al., "Preparation and electrochemical performance of polycrystalline and single crystalline $\mathrm{CuO}$ nanorods as anode materials for Li ion battery," Journal of Physical Chemistry B, vol. 108, no. 18, pp. 5547-5551, 2004.

[49] Q.-L. Zhang, Z.-M. Yang, B.-J. Ding, X.-Z. Lan, and Y.-J. Guo, "Preparation of copper nanoparticles by chemical reduction method using potassium borohydride," Transactions of Nonferrous Metals Society of China, vol. 20, no. 1, pp. s240-s244, 2010.

[50] J. M. Argüello, D. Raimunda, and T. Padilla-Benavides, "Mechanism of copper homeostasis in bacteria," Cellular and Infection Microbiology, vol. 3, no. 73, pp. 1-14, 2013.

[51] M. I. Samanovic, C. Ding, D. J. Thiele, and K. H. Darwin, "Copper in microbial pathogenesis: meddling with the metal," Cell Host and Microbe, vol. 11, no. 2, pp. 106-115, 2012.

[52] M. Raffi, S. Mehrwan, T. M. Bhatti et al., "Investigations into the antibacterial behavior of copper nanoparticles against Escherichia coli," Annals of Microbiology, vol. 60, no. 1, pp. 75-80, 2010.

[53] C. O. Dimkpa, A. Calder, D. W. Britt, J. E. McLean, and A. J. Anderson, "Responses of a soil bacterium, Pseudomonas chlororaphis $\mathrm{O} 6$ to commercial metal oxide nanoparticles compared with responses to metal ions," Environmental Pollution, vol. 159, no. 7, pp. 1749-1756, 2011.

[54] J. P. Ruparelia, A. K. Chatterjee, S. P. Duttagupta, and S. Mukherji, "Strain specificity in antimicrobial activity of silver and copper nanoparticles," Acta Biomaterialia, vol. 4, no. 3, pp. 707716, 2008.

[55] F. Rispoli, A. Angelov, D. Badia, A. Kumar, S. Seal, and V. Shah, "Understanding the toxicity of aggregated zero valent copper nanoparticles against Escherichia coli," Journal of Hazardous Materials, vol. 180, no. 1-3, pp. 212-216, 2010.

[56] S. Vinopal, T. Ruml, and P. Kotrba, "Biosorption of $\mathrm{Cd}^{2+}$ and $\mathrm{Zn}^{2+}$ by cell surface-engineered Saccharomyces cerevisiae," International Biodeterioration \& Biodegradation, vol. 60 , no. 2, pp. 96-102, 2007.

[57] E. Navarro, A. Baun, R. Behra et al., "Environmental behavior and ecotoxicity of engineered nanoparticles to algae, plants, and fungi," Ecotoxicology, vol. 17, no. 5, pp. 372-386, 2008.

[58] A. Orell, C. A. Navarro, R. Arancibia, J. C. Mobarec, and C. A. Jerez, "Life in blue: copper resistance mechanisms of bacteria and Archaea used in industrial biomining of minerals," Biotechnology Advances, vol. 28, no. 6, pp. 839-848, 2010.

[59] Y. Cui, Y. Zhao, Y. Tian, W. Zhang, X. Lü, and X. Jiang, “The molecular mechanism of action of bactericidal gold nanoparticles on Escherichia coli," Biomaterials, vol. 33, no. 7, pp. 2327-2333, 2012.
[60] T. P. Dasari, K. Pathakoti, and H.-M. Hwang, "Determination of the mechanism of photoinduced toxicity of selected metal oxide nanoparticles ( $\mathrm{ZnO}, \mathrm{CuO}, \mathrm{Co}_{3} \mathrm{O}_{4}$ and $\mathrm{TiO}_{2}$ ) to E. coli bacteria," Journal of Environmental Sciences, vol. 25, no. 5, pp. 882-888, 2013.

[61] W. Lee, K.-J. Kim, and D. G. Lee, "A novel mechanism for the antibacterial effect of silver nanoparticles on Escherichia coli," BioMetals, vol. 27, no. 6, pp. 1191-1201, 2014.

[62] C. Gunawan, W. Y. Teoh, C. P. Marquis, and R. Amal, "Cytotoxic origin of copper(II) oxide nanoparticles: comparative studies with micron-sized particles, leachate, and metal salts," ACS Nano, vol. 5, no. 9, pp. 7214-7225, 2011.

[63] L. Rastogi, A. J. Kora, and R. B. Sashidhar, "Antibacterial effects of gum kondagogu reduced/stabilized silver nanoparticles in combination with various antibiotics: a mechanistic approach," Applied Nanoscience, 2014.

[64] N. J. Watmough, G. Butland, M. R. Cheesman, J. W. B. Moir, D. J. Richardson, and S. Spiro, "Nitric oxide in bacteria: synthesis and consumption," Biochimica et Biophysica Acta, vol. 1411, no. 2-3, pp. 456-474, 1999.

[65] E. M. Hetrick, J. H. Shin, N. A. Stasko et al., "Bactericidal efficacy of nitric oxide-releasing silica nanoparticles," ACS Nano, vol. 2, no. 2, pp. 235-246, 2008.

[66] S. M. Deupree and M. H. Schoenfisch, "Morphological analysis of the antimicrobial action of nitric oxide on Gram-negative pathogens using atomic force microscopy," Acta Biomaterialia, vol. 5, no. 5, pp. 1405-1415, 2009.

[67] F. Mirzajani, H. Askari, S. Hamzelou et al., "Proteomics study of silver nanoparticles toxicity on Bacillus thuringiensis," Ecotoxicology and Environmental Safety, vol. 100, no. 1, pp. 122-130, 2014.

[68] I. Manconi, P. van der Maas, and P. Lens, "Effect of copper dosing on sulfide inhibited reduction of nitric and nitrous oxide," Nitric Oxide, vol. 15, no. 4, pp. 400-407, 2006.

[69] K. Bondarczuk and Z. Piotrowska-Seget, "Molecular basis of active copper resistance mechanisms in Gram-negative bacteria," Cell Biology and Toxicology, vol. 29, no. 6, pp. 397-405, 2013.

[70] I. Sondi and B. Salopek-Sondi, "Silver nanoparticles as antimicrobial agent: a case study on E. coli as a model for Gramnegative bacteria," Journal of Colloid and Interface Science, vol. 275, no. 1, pp. 177-182, 2004.

[71] R. M. Amin, M. B. Mohamed, M. A. Ramadan, T. Verwanger, and B. Krammer, "Rapid and sensitive microplate assay for screening the effect of silver and gold nanoparticles on bacteria," Nanomedicine, vol. 4, no. 6, pp. 637-643, 2009.

[72] H. K. Daima, P. Selvakannan, Z. Homan, S. K. Bhargava, and V. Bansal, "Tyrosine mediated gold, silver and their alloy nanoparticles synthesis: antibacterial activity toward gram positive and gram negative bacterial strains," in Proceedings of the International Conference on Nanoscience, Technology and Societal Implications (NSTSI '11), pp. 6-11, Bhubaneshwar, India, December 2011. 

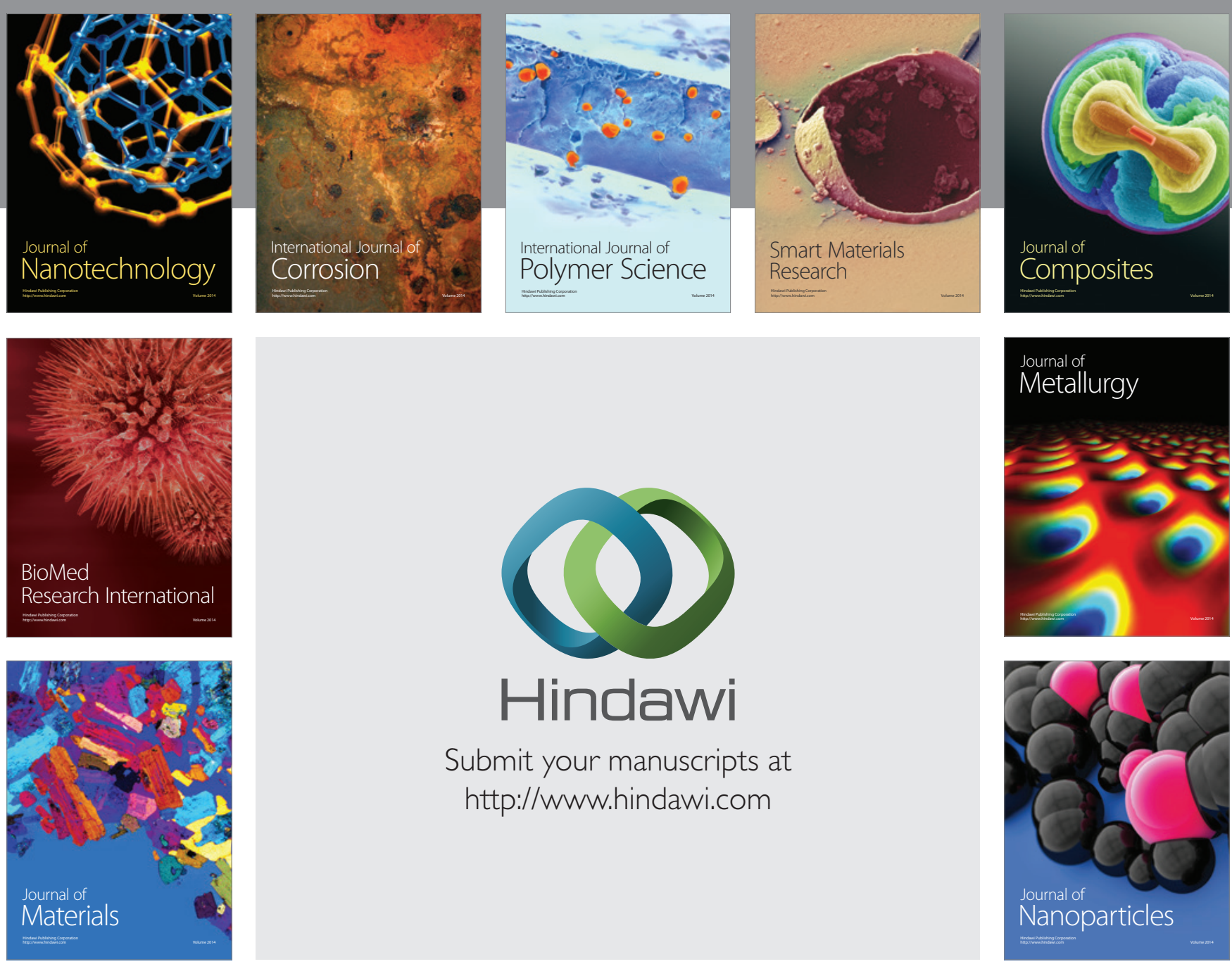

Submit your manuscripts at http://www.hindawi.com
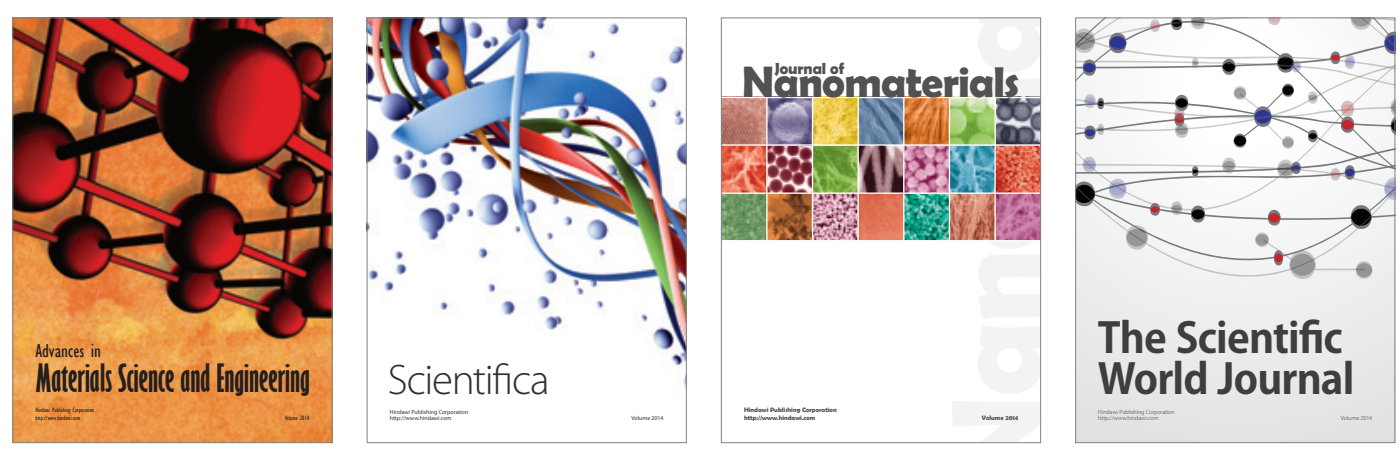

\section{The Scientific World Journal}
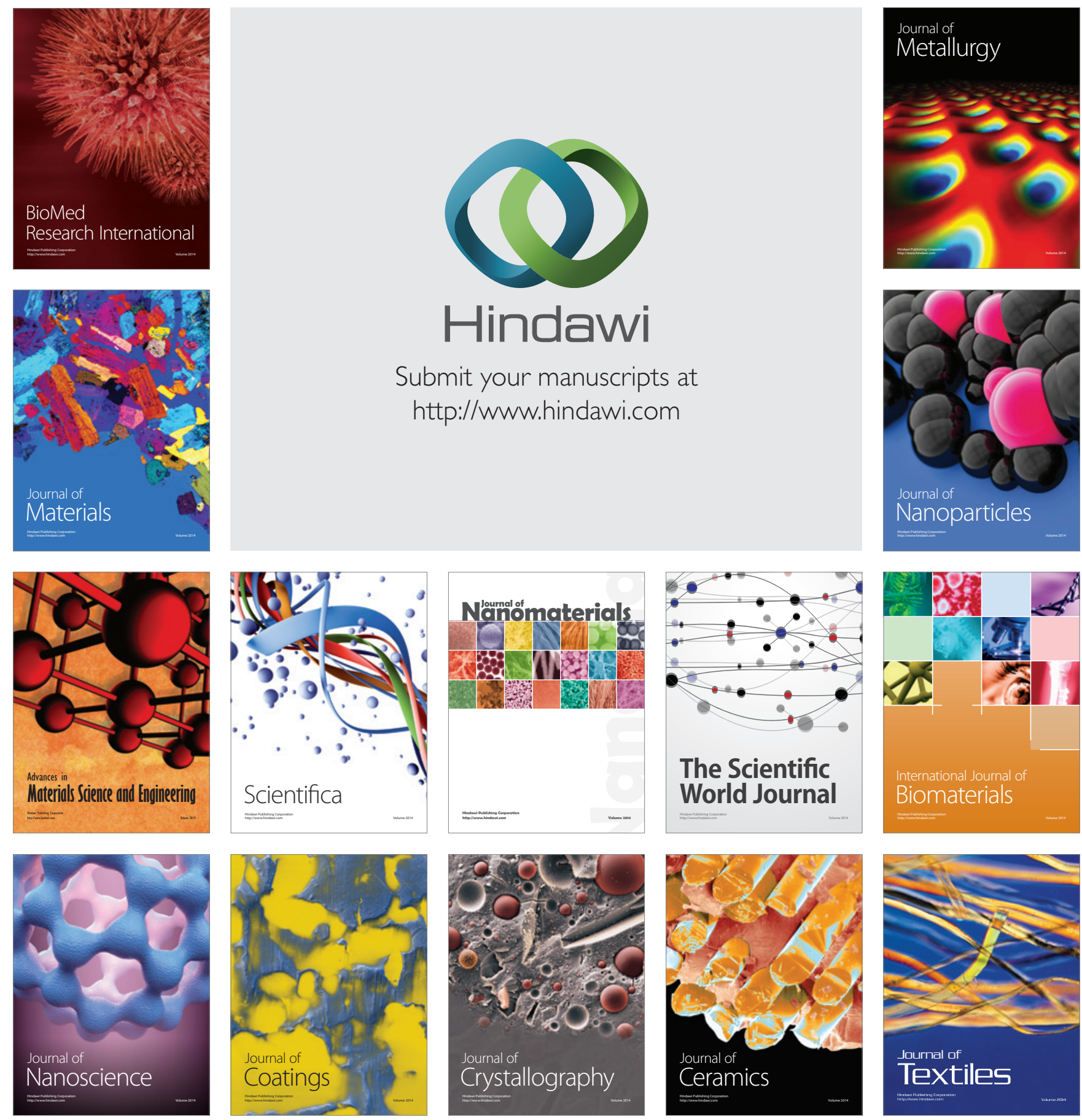